\title{
FECHAMENTO DE COMUNICAÇÃO BUCOSINUSAL: RELATO DE CASOS CLÍNICOS
}

Ana Paula BONOTTO, Bruna Maggioni TEIXEIRA, Laise BASSO, Nathália Gomes EKO, Ângelo José PAVAN

O seio maxilar é um espaço pneumático no interior do osso maxilar. Sua cavidade próxima dos ápices de dentes superiores posteriores permite que se forme acesso direto entre este e a cavidade bucal chamada comunicação bucosinusal(CB), comum em casos de extrações dentárias, lesões císticas, etc. Esta comunicação necessita de intervenção cirúrgica que pode ser realizada por deslocamento de retalhos. O objetivo deste relato de casos é apresentar dois casos com técnicas distintas para fechamento de CB. Primeiro caso, paciente P.V.. 52 anos, com suspeita de $C B$ na região do elemento 27, queixando-se saída de alimentos líquidos pelo nariz. Após exame clínico e radiográfico constatou-se comunicação. Realizou-se tratamento da comunicação com uso da técnica de Caldwell-Luc para curetagem da mucosa sinusal e deslocamento do corpo adiposo da bochecha para fechamento. Segundo caso, paciente K.H., 73 anos, relatou comunicação após extração. Ao exame clínico, paciente queixou-se de dor à palpação na parede lateral do seio e junto com exame radiográfico confirmou-se presença de comunicação. Foi adotado o protocolo de irrigação do seio maxilar durante 2 semanas, para após, ser realizado fechamento com deslocamento de retalho vestibular. Com a finalização desses casos observou-se fechamento completo das comunicações sendo consideradas técnicas de excelente prognóstico.

Palavras chave: Seio maxilar; Extração dentária; Ápice dentário. 